\title{
Spermadhesins of the AQN and AWN families, DQH sperm surface protein and HNK protein in the heparin-binding fraction of boar seminal plasma
}

\author{
V. Jonáková ${ }^{1}$, M. Kraus ${ }^{1}$, L. Veselský1 ${ }^{1}$, D. Čechová ${ }^{1}, K$. Bezouška ${ }^{2}$ and M. Tichá ${ }^{2}$ \\ 'Institute of Molecular Genetics, Academy of Sciences of the Czech Republic, Flemingovo nám. 2, 16637 Prague 6, Czech Republic; and \\ ${ }^{2}$ Department of Biochemistry, Charles University, Albertov 2030, 12840 Prague 2, Czech Republic
}

\begin{abstract}
Heparin-binding proteins (designated BHB-2-BHB-9) were isolated from boar seminal plasma by affinity chromatography on heparin immobilized on polyacrylamide gel, followed by reverse phase HPLC. According to their N-terminal amino acid sequences, BHB-3-BHB-5 belong to the AQN family of spermadhesins and BHB-7-BHB-9 to the AWN family. BHB-6 is composed of two different proteins. The dominant protein $(14 \mathrm{kDa})$ has the N-terminal amino acid sequence HNKQEGRDHD that is identical to the sequence of human semenogelin at positions 85-94. The minor proteins ( 16 and $17 \mathrm{kDa}$ ) belong to the AWN family of spermadhesins. The $14 \mathrm{kDa}$ HNK protein does not crossreact with antibodies against AQN or AWN spermadhesins. BHB-2 also binds to the acrosome of boar epididymal spermatozoa but has the $\mathrm{N}$-terminal sequence $\mathrm{DQH}$. Therefore, basic protein BHB-2 belongs to a new family of DQH sperm surface proteins that are homologous to the acidic proteins from bull and stallion seminal plasma, to the collagen binding domain II in fibronectin and to the leucocyte cell-cell adhesion regulator, but are not homologous to AQN or AWN spermadhesins. Nevertheless, antiAQN-1 spermadhesin antibodies crossreact strongly with $\mathrm{DQH}$ protein. All boar heparin-binding proteins bind concanavalin A indicating their glycoprotein nature, which was proved by the detection of glucosamine and galactosamine residues in their molecules. Furthermore, spermadhesins interact with zona pellucida, protease inhibitors and a polyacrylamide derivative of heparin. Affinity chromatography experiments showed that the $\mathrm{DQH}$ protein bound to gelatin-agarose together with the AWN proteins and that the DQH protein and AQN-1 spermadhesin belong to the phosphoryl choline binding proteins.
\end{abstract}

\section{Introduction}

Mammalian fertilization is a complex process involving a series of events that include sperm capacitation, gamete recognition and binding to the ovum. A series of interactions between molecules located on the surface of both gametes participate in the individual events of fertilization.

Boar spermadhesins are multifunctional proteins located on the sperm surface (Jonáková et al., 1995; Töpfer-Petersen et al., 1995) that participate in various types of interaction either with components of the zona pellucida or with substances that are present in the natural environment of both gametes. Some physicochemical and binding properties of spermadhesins of the $A Q N$ and $A W N$ families and porcine seminal plasma protein I (PSP-I) spermadhesin have already been described (Calvete et al., 1993a; Kwok et al., 1993; Sanz et

${ }^{*}$ Correspondence.

Received 13 October 1997. al., 1993; Jonáková et al., 1995; Liberda et al., 1997a; Tichá et al., 1998). Some spermadhesins interact with the zona pellucida (Jonáková et al., 1991; Parry et al., 1992; Calvete et al., 1993a; Töpfer-Petersen et al., 1995). In addition, some have an affinity for heparin and bind protease inhibitors (Parry et al., 1992; Sanz et al., 1992; Calvete et al., 1993b). Previous studies showed that the binding properties of $A Q N$ and $A W N$ spermadhesins depend on their glycosylation (Calvete et al., 1993a; Calvete et al., 1993b). The complete amino acid sequences of several spermadhesins have been reported (AQN-1, AQN-3, AWN, PSP-I, PSP-II, bovine acid seminal fluid protein (aSFP)). These proteins are composed of 109-133 amino acid residues, contain two conserved disulphide bridges and have $40-60 \%$ amino acid sequence identity (reviewed in Töpfer-Petersen et al., 1995).

The present study deals with a detailed characterization of separated proteins of the heparin-binding fraction of boar seminal plasma. Attention was focused on comparison of the immunological and binding properties of spermadhesins of 
the AQN and AWN subfamilies with those of DQH sperm surface protein and HNK protein to gain a better understanding of the role of these spermadhesins in vivo.

\section{Materials and Methods}

\section{Materials}

Boar semen was obtained from healthy Large White pigs from the Insemination Station, Nové Mlýny. Pig ovaries (Large White), pig blood serum, boar cauda epididymal fluid and mice spleens were obtained from slaughtered animals and stored frozen at $-70^{\circ} \mathrm{C}$. Boar seminal plasma was isolated from sperm ejaculate by centrifugation at $600 \mathrm{~g}$ for $20 \mathrm{~min}\left(5^{\circ} \mathrm{C}\right)$. Boar cauda epididymal spermatozoa were obtained from the epididymal fluid of slaughtered animals. Spermatozoa were washed three times with PBS ( $\mathrm{pH} 7.2$, $0.15 \mathrm{~mol}$ phosphate $\mathrm{l}^{-1}, 0.3 \mathrm{~mol} \mathrm{NaCl} \mathrm{l^{-1 }}$ ) to remove epididymal fluid, followed by centrifugation at $600 \mathrm{~g}$ for $5 \min \left(5^{\circ} \mathrm{C}\right)$.

Heparin and bovine trypsin kallikrein inhibitor (TKI) were obtained from Léčiva (Praha). Avidin, avidin-peroxidase, fluorescein isothiocyanate (FITC), 2,2'-azino-bis(3ethylbenzthiazoline-6-sulphonic acid) (ABTS), Nhydroxysuccinimidobiotin, gelatin-agarose and phosphoryl choline were purchased from Sigma (St Louis, MO). Soya bean Kunitz trypsin inhibitor (STI) was purchased from Boehringer Mannheim (Mannheim). Concanavalin A was obtained from the Laboratory for Production and Control of Lectin Preparations (Praha). 4-Chloro-1-naphthol was supplied by Serva (Heidelberg) and o-phenylenediamine was obtained from Fluka (Buchs).

Nitrocellulose membranes (RPN 203G Hybond C-Super) were obtained from Amersham (Amersham). Dialysis membranes (Spectra/PorR Membrane MWCO 6-8000) were supplied by Roth (Karlsruhe). Servalyt Pre Cotes and Servalyt Pre Nets, both $\mathrm{pH} 3-10$, the pI calibration kit $(\mathrm{pH}$ range 3-10) and the low molecular mass protein standards were purchased from Serva (Heidelberg).

Immobilization of heparin was achieved by coupling the polysaccharide to poly(acrylamide-allylamine) copolymer using the carbodiimide reaction as described by Tichá $e$ al al. (1994). A water soluble poly(acrylamide-allylamine) derivative of heparin was prepared using the method of Klein et al. (1995). The reaction described by Liberda et al. (1997b) was used for the preparation of a fluorescein-labelled derivative of avidin (FITC-avidin).

\section{Purification of heparin-binding proteins}

Boar seminal plasma stored at $-20^{\circ} \mathrm{C}$ was thawed and centrifuged for $10 \mathrm{~min}$ at $10000 \mathrm{~g}$. The seminal plasma was then diluted 1:1 with PBS ( $\mathrm{pH} 7.3,20 \mathrm{mmol}$ phosphate $\mathrm{l}^{-1}$ containing $150 \mathrm{mmol} \mathrm{NaCl} \mathrm{l}^{-1}$ ) and applied $(50 \mathrm{ml})$ to a heparin-polyacrylamide column $(30 \mathrm{~mm} \times 75 \mathrm{~mm})$ preequilibrated with the same buffer (Tichá et al., 1994). Nonadsorbed proteins were washed off with the starting buffer and the bound proteins were eluted with $3 \mathrm{~mol} \mathrm{NaCl} \mathrm{l}{ }^{-1}$.
Fractions containing heparin-binding proteins (designated BHB-2-BHB-9) were pooled, desalted on Sephadex G-25 (Pharmacia, Uppsala) in $0.2 \%$ acetic acid and lyophilized. Further purification of heparin-binding proteins was achieved by reverse phase HPLC on a semipreparative $218 \mathrm{TP} 1010$ Vydac $\mathrm{C}_{18}$ column $(10 \mathrm{~mm} \times 250 \mathrm{~mm}, 10 \mu \mathrm{m}$ particle size). $5 \mathrm{mg}$ of protein preparation in $1 \mathrm{ml} 0.05 \%$ trifluoroacetic acid was applied to the column and the separated proteins were eluted with linear gradients of $30-60 \%$ acetonitrile ( $75 \mathrm{~min}$ ) followed by $60-80 \%$ acetonitrile (15 min). Rechromatography of BHB-2, BHB-3, BHB-6 and BHB-7 was carried out on an analytical 218 TP 104 Vydac $C_{18}$ column $(4.6 \mathrm{~mm} \times 250 \mathrm{~mm}, 5 \mu \mathrm{m}$ particle size $)$ in $0.05 \%$ trifluoroacetic acid in water, with a linear gradient of either $20-40 \%$ acetonitrile (60 min, BHB-2 and BHB-3) or $25-40 \%$ acetonitrile (50 $\mathrm{min}, \mathrm{BHB}-6$ and BHB-7). Protein fractions were lyophilized.

\section{Affinity chromatography}

Gelatin-agarose. Heparin-binding fraction $(10 \mathrm{mg})$ was applied to a gelatin-agarose column $(1 \mathrm{~cm} \times 5 \mathrm{~cm})$ equilibrated with PBS ( $\mathrm{pH}$ 7.4). Non-adsorbed proteins were eluted with the starting buffer; adsorbed proteins were eluted with $4 \mathrm{~mol}_{\text {urea }} \mathrm{l}^{-1}$ in PBS at a flow rate of $3 \mathrm{ml}$ $(20 \mathrm{~min})^{-1}$. Fractions containing proteins (as determined by absorbance at $280 \mathrm{~nm}$ ) were collected, desalted on Sephadex G-25 in $0.2 \%$ acetic acid and lyophilized. The protein preparations obtained were analysed by reverse phase HPLC and SDS-PAGE.

Heparin-polyacrylamide gel followed by phosphoryl choline elution. Boar seminal plasma $(50 \mathrm{ml})$ was applied to the heparin-polyacrylamide gel column $(1.5 \mathrm{~cm} \times 15 \mathrm{~cm})$ equilibrated with $0.05 \mathrm{~mol}$ Tris- $\mathrm{HCl} 1^{-1}$ buffer ( $\mathrm{pH} 7.4$, containing $0.15 \mathrm{~mol} \mathrm{NaCl} \mathrm{l}^{-1}$ ) as described by Tichá et al. (1994). The non-adsorbed proteins were eluted with the same buffer; the adsorbed proteins were first eluted with $0.05 \mathrm{~mol}$ Tris- $\mathrm{HCl}^{-1}$ buffer (containing $0.15 \mathrm{~mol} \mathrm{NaCl} \mathrm{l}^{-1}$ and $0.01 \mathrm{~mol}$ phosphoryl choline $\mathrm{l}^{-1}, \mathrm{pH}$ 7.4) and then with $3 \mathrm{~mol} \mathrm{NaCl}^{-1}$ at a flow rate of $3 \mathrm{ml}(15 \mathrm{~min})^{-1}$. Further preparation and analysis of the protein fractions were carried out as described for the affinity chromatography on gelatin-agarose.

\section{Preparation of solubilized zona pellucida}

Oocytes were released from pig ovaries (either fresh or frozen) in a commercial meat grinder with a large amount of ice-cold saline $\left(0.15 \mathrm{~mol} \mathrm{NaCl} \mathrm{l}^{-1}\right)$ and the homogenate was sieved through nylon screens as described by Hedrick and Wardrip (1986). The oocytes were separated from other particles by centrifugation in a discontinuous Percoll gradient according to the method of Hokke et al. (1994). The oocytes were collected from the $10-20 \%$ interface, washed with distilled water and gently homogenized using a small glass homogenizer. The zona pellucida 'ghosts' were then collected on a $40 \mu \mathrm{m}$ screen and repeatedly washed with saline. Isolated zonae pellucidae were heat solubilized in 
$0.2 \mathrm{~mol} \mathrm{NaHCO}_{3} \mathrm{l}^{-1}(\mathrm{pH} 9.0)$ at $73^{\circ} \mathrm{C}$ for $30 \mathrm{~min}$ and centrifuged at $350 \mathrm{~g}$ for $10 \mathrm{~min}\left(4^{\circ} \mathrm{C}\right)$. The clear supernatant with a protein concentration of $0.32 \mathrm{mg} \mathrm{ml}^{-1}$ was used for biotinylation.

\section{Preparation of antisera}

Rabbit antiserum to both AQN-1 and AWN-1 spermadhesins was prepared by immunizing female rabbits with an intracutaneous injection of $1 \mathrm{mg}$ highly purified protein dissolved in $0.1 \mathrm{ml}$ of $0.15 \mathrm{~mol} \mathrm{NaCl}{ }^{-1}$ mixed with Freund's complete adjuvant. At intervals of 2 and 4 months after the initial immunization, the rabbits were injected with $500 \mu \mathrm{g}$ of the antigen in Freund's complete adjuvant. Two weeks after the last injection, the animals were bled through the ear vein. The antisera were heat inactivated for $30 \mathrm{~min}$ at $56^{\circ} \mathrm{C}$. After immunoelectrophoresis (Williams, 1971), a single precipitation line was seen in the reaction of antiserum to AQN-1 and AWN-1 with the corresponding antigen. The specificity of both antisera was determined by ELISA. In both cases, preincubation $\left(2 \mathrm{~h}\right.$ at $37^{\circ} \mathrm{C}$ and overnight at $4^{\circ} \mathrm{C}$ ) of $200 \mu \mathrm{g}$ of the antigen (AQN-1 or AWN-1) with $0.1 \mathrm{ml}$ of the corresponding antiserum (anti-AQN-1 or anti-AWN-1, respectively) resulted in a negative reaction.

\section{Preparation of splenocytes}

Mice spleens were homogenized in PBS ( $\mathrm{pH} 7.2$ ) and the cell suspension was passed through a $110 \mu \mathrm{m}$ mesh. The suspension was then washed by centrifugation in PBS at $400 \mathrm{~g}(3 \times 5 \mathrm{~min})$ and adjusted to $5 \times 10^{6} \mathrm{cells} \mathrm{ml}^{-1}$ PBS containing $250,100,20$ or $1 \mu \mathrm{g}$ of BHB-2. After $30 \mathrm{~min}$ incubation at $37^{\circ} \mathrm{C}$, a drop of the cell suspension was placed onto a microscope slide and cell agglutination was evaluated under the microscope.

\section{Amino acid analysis and $N$-terminal sequence determination}

Amino acid analyses were carried out using a Biochrom 20 analyser (Pharmacia Biotech, Uppsala) after sample hydrolysis with $6 \mathrm{~mol} \mathrm{HCl} 1^{-1}$ at $110^{\circ} \mathrm{C}$ for $20 \mathrm{~h}$. For quantitation of free cysteine residues and disulphide bridges in BHB-2, the protein was treated with iodoacetamide either directly or after reduction (boiled in 1\% 2-mercaptoethanol) (see Einspanier et al., 1994). Carboxymethylcysteine was determined after hydrolysis for $24 \mathrm{~h}$. For amino sugar analyses, the samples were hydrolysed with $4 \mathrm{~mol} \mathrm{HCl}^{-1}$ at $110^{\circ} \mathrm{C}$ for $4 \mathrm{~h}$ and analysed using a T339 amino acid analyser (Mikrotechna, Praha). N-terminal amino acid sequences were determined automatically on the Applied Biosystems 470 A protein sequencer. Program 02R PTH was used and phenylthiohydantoin derivatives of the amino acid residues were analysed by HPLC (Tsunasawa et al., 1985). N-terminal acid sequencing of BHB-2 and the proteins from BHB- 6 was performed using a gas-liquid phase protein sequencer (Beckman LF 3600, Fullerton, CA) following the manufacturer's instructions. Searches for amino acid similarities were carried out using the protein sequence deposits in the BLAST-BASIC e-mail server databank (Altschul et al., 1990).

\section{Electrophoresis and blotting}

SDS-PAGE was carried out on $15 \%$ slab gels as described by Laemmli (1970) and blotting onto nitrocellulose sheets was carried out as described by Towbin et al. (1979). The molecular mass of separated proteins was estimated by comparison with low molecular mass protein standards run in parallel.

Solid phase protein-binding assay on nitrocellulose sheets was carried out using the following procedure. After blotting, the proteins separated by electrophoresis were deactivated in buffer $\left(0.01 \mathrm{~mol}\right.$ Tris- $-\mathrm{HCl} \mathrm{l^{-1 }}$ (pH 7.4), $0.85 \%$ $(\mathrm{w} / \mathrm{v}) \mathrm{NaCl}, 3 \%(\mathrm{w} / \mathrm{v}) \mathrm{BSA}, 0.02 \%(\mathrm{v} / \mathrm{v})$ Tween 20$)$ for $2 \mathrm{~h}$ at $22^{\circ} \mathrm{C}$. The blots were then incubated for $2 \mathrm{~h}$ at $37^{\circ} \mathrm{C}$ with biotinylated zona pellucida $\left(5 \mu \mathrm{g} \mathrm{ml}^{-1}\right)$ in washing buffer $\left(0.01 \mathrm{~mol}\right.$ Tris- $-\mathrm{HCl} \mathrm{l}{ }^{-1}(\mathrm{pH} 7.4), 0.85 \%(\mathrm{w} / \mathrm{v}) \mathrm{NaCl}, 3 \mathrm{mmol}$ $\left.\mathrm{CaCl}_{2} \mathrm{l}^{-1}\right)$, washed, and incubated for $1 \mathrm{~h}$ at $37^{\circ} \mathrm{C}$ with avidin-peroxidase in buffer $\left(0.1 \mathrm{~mol}\right.$ Tris- $\mathrm{HCl} \mathrm{l}^{-1}(\mathrm{pH} 8.0) 1 \%$ $(w / v)$ BSA). The blots were then washed again and developed at $20^{\circ} \mathrm{C}$ in the dark by treatment with $0.05 \%$ 4-chloro-1-naphthol in $0.01 \mathrm{~mol}$ Tris- $\mathrm{HCl} \mathrm{l^{-1 }}$ (pH 7.4) containing $0.001 \%(\mathrm{w} / \mathrm{v}) \mathrm{CoCl}_{2}$ and $0.09 \%(\mathrm{v} / \mathrm{v}) \mathrm{H}_{2} \mathrm{O}_{2}$. The reaction was stopped after $5 \mathrm{~min}$ by washing the blots in distilled water.

\section{Isoelectric focusing}

Isoelectric focusing (IEF) was carried out on a FBA 3000 (Pharmacia, Uppsala) using polyacrylamide layer Servalyt Pre Cotes $3-10$ and a pI calibration kit ( $\mathrm{pH} 3-10)$. The conditions for IEF were as described in the manufacturer's manual. Proteins were stained with Coomassie brilliant blue R-250. Servalyt Pre Nets 3-10 were used for electroblotting of separated proteins to nitrocellulose. Proteins resolved by IEF were transferred immediately to a nitrocellulose membrane in a semi-dry electroblotter (Omni-Trans, Omni-Bio, Brno). Electrotransfer was conducted at a current density of $0.8 \mathrm{~A}$ $\mathrm{cm}^{-2}$ in 0.05 mol citrate phosphate $\mathrm{l}^{-1}(\mathrm{pH} 4.6)$ or in $0.05 \mathrm{~mol}$ Tris- $\mathrm{HCl} \mathrm{l}^{-1}(\mathrm{pH} 8.5)$ for $90 \mathrm{~min}$.

\section{Biotinylation of sperm proteins and ligands}

The biotinylation of a water-soluble poly(acrylamideallylamine) derivative of heparin was as described by Klein et al. (1995). The spermadhesins BHB-2, BHB-3 and BHB-7, solubilized zona pellucida, bovine TKI and STI were incubated with $0.4 \% \quad \mathrm{~N}$-hydroxysuccinimidobiotin in dimethylformamide for $30 \mathrm{~min}$ at $25^{\circ} \mathrm{C}$. The reaction was stopped by addition of $1 \mathrm{~mol} \mathrm{NH}_{4} \mathrm{Cl} \mathrm{l}^{-1}$ to adjust the $\mathrm{pH}$ to 6.0. The biotinylated proteins were dialysed on Spectra/Por MWCO 6/8000 membranes against $1 \mathrm{mmol} \mathrm{HCl}^{-1}$ and were used immediately. Biotinylated zona pellucida (stock solution $220 \mu \mathrm{g} \mathrm{ml}^{-1}$ ) was dialysed against $20 \mathrm{mmol}$ Tris- $\mathrm{HCl}$ $\mathrm{l}^{-1}\left(\mathrm{pH} 7.8,0.4 \mathrm{~mol} \mathrm{NaCl} 1^{-1}\right)$ and stored at $-20^{\circ} \mathrm{C}$. 


\section{Enzyme-linked binding assay (ELBA)}

For the ligand-binding assay, the proteins $(1.0-2.5 \mu \mathrm{g})$ were immobilized on microtitration plates (Dynatech, Chantilly, VA) in $100 \mu \mathrm{l}$ of coating buffer $\left(0.05 \mathrm{~mol} \mathrm{NaHCO}_{3}\right.$ $\mathrm{l}^{-1}, \mathrm{pH}$ 9.6) by incubation overnight at $4^{\circ} \mathrm{C}$. After rinsing with washing buffer $\left(0.01 \mathrm{~mol}\right.$ Tris $\mathrm{HCl} \mathrm{l}^{-1}(\mathrm{pH} 7.4) 0.85 \%(\mathrm{w} / \mathrm{v})$ $\left.\mathrm{NaCl}, 3 \mathrm{mmol} \mathrm{CaCl} \mathrm{l}^{-1}, 0.5 \%(\mathrm{w} / \mathrm{v}) \mathrm{BSA}\right)$, the wells were deactivated with $250 \mu \mathrm{l}$ of $3 \%(\mathrm{w} / \mathrm{v})$ BSA in washing buffer $\left(2 \mathrm{~h}\right.$ at $\left.4^{\circ} \mathrm{C}\right)$. After washing, biotinylated water soluble polyacrylamide derivative of heparin $(5 \mu \mathrm{g})$, biotinylated solubilized zona pellucida $(0.5 \mu \mathrm{g})$, or proteinase inhibitor $(2 \mu \mathrm{g})$, each in $100 \mu \mathrm{l}$ of washing buffer, was applied to the assay wells and incubated for $2 \mathrm{~h}$ at $37^{\circ} \mathrm{C}$. After washing, 25 ng avidin-peroxidase in $100 \mu \mathrm{l}$ of $0.1 \mathrm{~mol}$ Tris- $\mathrm{HCl} \mathrm{l}^{-1}(\mathrm{pH}$ 8.0) containing $1 \%(\mathrm{w} / \mathrm{v}) \mathrm{BSA}$ was added and incubated for $1 \mathrm{~h}$ at $37^{\circ} \mathrm{C}$. After washing, the enzyme reaction was initiated by the addition of $250 \mu 10.01 \%(\mathrm{w} / \mathrm{v})$ ABTS in $0.1 \mathrm{~mol}$ citrate phosphate $\mathrm{l}^{-1}(\mathrm{pH} 4.6)$ in the presence of $0.09 \%(\mathrm{v} / \mathrm{v}) \mathrm{H}_{2} \mathrm{O}_{2}$ into each well and developed at $37^{\circ} \mathrm{C}$. Absorbance was measured at $405 \mathrm{~nm}$ after $30 \mathrm{~min}$ using a microplate reader (SLT-Spectra, SLT-Labinstruments, Vienna).

\section{Enzyme-linked immunosorbent assay}

Wells in the assay plates were primed overnight at $4^{\circ} \mathrm{C}$ with antigens $\left(1.0-2.5 \mu \mathrm{g}(100 \mu \mathrm{l})^{-1}\right)$ in coating buffer $(0.05$ mol $\mathrm{NaHCO}_{3} \mathrm{l}^{-1}, \mathrm{pH}$ 9.6). After rinsing with washing buffer (PBS (pH 7.2) containing $0.5 \%(\mathrm{w} / \mathrm{v})$ BSA and $0.05 \%(\mathrm{v} / \mathrm{v})$ Tween 20 or $2 \%(\mathrm{v} / \mathrm{v})$ calf serum), the wells were deactivated with $250 \mu \mathrm{l}$ of $3 \%(\mathrm{w} / \mathrm{v}) \mathrm{BSA}$ in washing buffer for $2 \mathrm{~h}$ at $4^{\circ} \mathrm{C}$. After further rinsing with washing buffer, the antisera to spermadhesins (serial dilutions in PBS-Tween) were added to each well, and the plates were incubated at $22^{\circ} \mathrm{C}$ for $1 \mathrm{~h}$. After thorough washing, the spermadhesin antibodies were reacted with peroxidase-labelled goat anti-rabbit globulin in washing buffer $\left(1: 5000 ; 100 \mu \mathrm{l}\right.$ per well) at $22^{\circ} \mathrm{C}$ for $30 \mathrm{~min}$, washed again, and the bound peroxidase activity was detected using $0.5 \%(\mathrm{w} / \mathrm{v}) o$-phenylenediamine and $0.03 \%$ $(\mathrm{v} / \mathrm{v}) \mathrm{H}_{2} \mathrm{O}_{2}$ as a substrate in $0.1 \mathrm{~mol}$ citrate phosphate $\mathrm{l}^{-1} \mathrm{pH}$ 5.5). The reaction was stopped after $30 \mathrm{~min}$ with $4.5 \mathrm{~mol}$ $\mathrm{H}_{2} \mathrm{SO}_{4} \mathrm{l}^{-1}(50 \mu \mathrm{l}$ per well), and the absorbance was determined at $492 \mathrm{~nm}$ using an ELISA reader.

\section{Sperm-binding activity}

The sperm-binding activity of biotinylated BHB-2 protein was tested with epididymal spermatozoa. The washed epididymal spermatozoa $\left(1 \times 10^{5}\right.$ cells per well $)$ were immobilized on plates in $100 \mu \mathrm{l}$ of coating buffer $(0.05 \mathrm{~mol}$ $\mathrm{NaHCO}_{3} \mathrm{l}^{-1}, \mathrm{pH}$ 9.6) overnight at $4^{\circ} \mathrm{C}$. The immobilized spermatozoa were incubated with serially diluted biotinylated BHB-2 protein $\left(2.5 \mu \mathrm{g}(100 \mu \mathrm{l})^{-1}\right)$ dissolved in washing buffer $\left(100 \mu \mathrm{l}\right.$ per well) for $2 \mathrm{~h}$ at $37^{\circ} \mathrm{C}$. The spermatozoa were then washed and treated with avidin-peroxidase in washing buffer $\left(25 \mathrm{ng}(100 \mu \mathrm{ll})^{-1}\right)$ for $1 \mathrm{~h}$ at $37^{\circ} \mathrm{C}$. After further washing, the enzyme reaction was developed for $30 \mathrm{~min}$ at $37^{\circ} \mathrm{C}$ with ABTS using the procedure described above for the ELBA. The absorbance was measured at $405 \mathrm{~nm}$.

Binding of boar heparin-binding proteins to epididymal spermatozoa was studied using a fluorescence microscope (Leitz Orthoplan, Vienna). Epididymal spermatozoa were smeared on clean glass slides, air-dried and then preincubated for $30 \mathrm{~min}$ at $37^{\circ} \mathrm{C}$ in PBS containing 100 or $50 \mu \mathrm{g}$ heparin-binding protein $\mathrm{ml}^{-1}$. After washing (PBS, $0.2 \%(\mathrm{w} / \mathrm{v}) \mathrm{BSA})$, spermatozoa were incubated for $1 \mathrm{~h}$ at $22^{\circ} \mathrm{C}$ with FITC-avidin $\left(70 \mu \mathrm{g} \quad \mathrm{PBS} \mathrm{ml}^{-1}\right)$. The epididymal spermatozoa used as controls were prepared in the same way but without heparin-binding protein.

\section{Results}

\section{Isolation and characterization}

Heparin-binding proteins from boar seminal plasma were isolated by affinity chromatography on heparin immobilized on polyacrylamide gel. Individual proteins were separated by reverse phase HPLC and eight fractions (designated BHB2-BHB-9) were obtained and characterized by relative molecular mass (Fig. 1). Rechromatography was used for further purification of BHB-2, BHB-3, BHB- 6 and BHB-7. Purified protein fractions were characterized by amino acid analysis and $\mathrm{N}$-terminal sequence determination (Table 1). Most of the proteins are of basic character with relatively high isoelectric points ( $\mathrm{pI}$ values in the range 8.5-9.3), with the exception of the BHB- 6 fraction (Table 1). Single Nterminal amino acid sequences were determined for all of the protein fractions obtained, with the exception of BHB- 6 and BHB-9. These results showed that proteins in the BHB3-BHB-5 fractions belong to the AQN family of spermadhesins, and proteins in the BHB-7-BHB-9 fractions belong to the AWN family of spermadhesins (Jonáková et al., 1991; Sanz et al., 1993). One protein in each of the BHB-6 and BHB-8 fractions belongs to the AWN family. The N-terminal amino group of the $70 \mathrm{kDa}$ protein of the BHB- 8 fraction was blocked and was not characterized further. Similarly, the Nterminal amino group of the BHB-9 protein was blocked, but according to amino acid analysis, the protein belongs to the AWN family of spermadhesins. The second protein component of BHB-6 $\left(M_{\mathrm{r}} 14 \mathrm{kDa}\right)$ possesses the N-terminal amino acid sequence HNKQEGRDHD (HNK protein) that is identical to the amino acid sequence at positions 85-94 of semenogelin (Lilja et al., 1989) (Table 1).

The N-terminal amino acid structure of BHB-2 is different from other boar spermadhesins so far characterized; it starts with the sequence DQH (Table 1). Searches for amino acid similarities showed that this DQH protein is characterized by homology to the main acidic proteins of bull seminal plasma (PDC-109 and BSP-A3), to HSP-1 and HSP-2 of stallion seminal plasma, and to the adhesion inducing protein (pAIF-1) previously isolated from boar seminal vesicle fluid (Fig. 2). The amino acid composition of BHB-2 differs from those of $\mathrm{AWN}$ and $\mathrm{AQN}$ proteins, especially in the half-cysteine content. BHB-2 contains more than seven half-cysteine residues as determined by the amino acid analysis (results not shown). The iodoacetamide treatment 


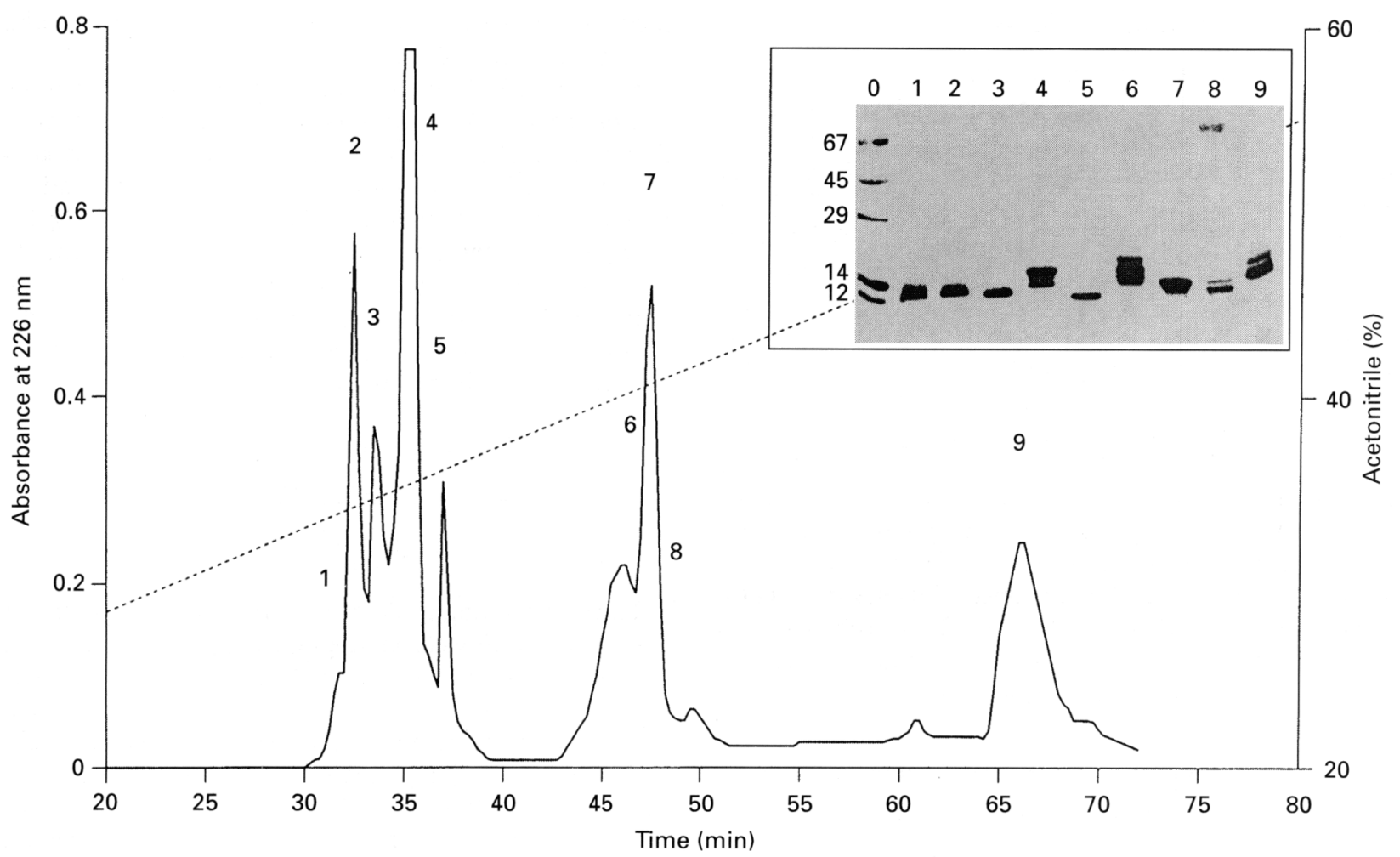

Fig. 1. Purification by reverse phase HPLC of boar seminal plasma proteins bound to heparin-polyacrylamide affinity column. Isolation of boar heparin-binding proteins was achieved by reverse phase HPLC on a $218 \mathrm{TP} 1010 \mathrm{Vydac} \mathrm{C}_{18}$ column in $0.05 \%$ trifluoroacetic acid with a linear gradient of $30-60 \%$ acetonitrile $(75 \mathrm{~min})$ followed by $60-80 \%$ acetonitrile ( $15 \mathrm{~min})$. Absorbance at $226 \mathrm{~nm}$ (-); acetonitrile gradient (-----). The inset shows SDS-PAGE of the chromatographic fractions under non-reducing conditions. Lane 0, standard molecular mass markers in $\mathrm{kDa}$ (bovine serum albumin, egg albumin, carbonic anhydrase, ribonuclease, cytochrome C); lanes 2-9, purified heparin-binding proteins in fractions BHB-2-BHB-9.

Table 1. N-terminal amino acid sequences of boar heparin-binding proteins obtained by reverse phase HPLC

\begin{tabular}{|c|c|c|c|c|}
\hline Heparin-binding protein & Protein & $M_{\mathrm{r}}(\mathrm{kDa})$ & $\mathrm{pI}$ & $\mathrm{N}$-terminal amino acid residues \\
\hline & & & & 20 \\
\hline \multirow[t]{4}{*}{ BHB-2 } & \multirow[t]{4}{*}{$\mathrm{DQH}$} & \multirow[t]{4}{*}{13} & \multirow[t]{4}{*}{8.6} & DQHLPGRFLTPAITSDDKCV \\
\hline & & & & \multirow{2}{*}{$\begin{array}{l}21 \\
\text { FPFIYKGNLYFDCTLHDSTYY }\end{array}$} \\
\hline & & & & \\
\hline & & & & $1 \quad 8$ \\
\hline \multirow[t]{2}{*}{ BHB-3 } & \multirow[t]{2}{*}{$\mathrm{AQN}-1$} & \multirow[t]{2}{*}{13} & \multirow[t]{2}{*}{9.0} & AQNKGPHK \\
\hline & & & & $1 \quad 10$ \\
\hline \multirow[t]{2}{*}{ BHB-4 } & \multirow[t]{2}{*}{ AQN-2 } & \multirow[t]{2}{*}{14,16} & \multirow[t]{2}{*}{$9.3 ; 9.5$} & AQNKGSDDXD \\
\hline & & & & $1 \quad 8$ \\
\hline \multirow[t]{2}{*}{ BHB-5 } & \multirow[t]{2}{*}{ AQN-3 } & \multirow[t]{2}{*}{12} & \multirow[t]{2}{*}{9.4} & AQNKGSDD \\
\hline & & & & $1 \quad 10$ \\
\hline \multirow[t]{4}{*}{ BHB-6 } & \multirow[t]{2}{*}{$\mathrm{HNK}^{\mathrm{a}}$} & \multirow[t]{2}{*}{14} & \multirow[t]{2}{*}{6.9} & HNKQEGRDHD \\
\hline & & & & $1 \quad 10$ \\
\hline & \multirow[t]{2}{*}{ AWN-1 } & \multirow[t]{2}{*}{16,17} & \multirow[t]{2}{*}{$9.0 ; 9.3$} & AWNRRSRSXGG \\
\hline & & & & 110 \\
\hline \multirow[t]{2}{*}{ BHB-7 } & \multirow[t]{2}{*}{ AWN-1 } & \multirow[t]{2}{*}{14} & \multirow[t]{2}{*}{9.3} & AWNRRSRSXGG \\
\hline & & & & 110 \\
\hline \multirow[t]{2}{*}{ BHB-8 } & AWN-1 & 14 & 8.7 & AWNRRSRSXG \\
\hline & $\mathrm{P}-70^{\mathrm{b}}$ & 70 & 6.4 & $\mathrm{~N}$-terminus blocked \\
\hline BHB-9 & AWN-2 & 16 & 6.4 & $\mathrm{~N}$-terminus blocked \\
\hline
\end{tabular}

${ }^{a}$ Dominant $\mathrm{N}$-terminal sequence $(66 \%)$ found in BHB- 6 .

bP-70: protein that immunoreacted with anti-AWN serum. 


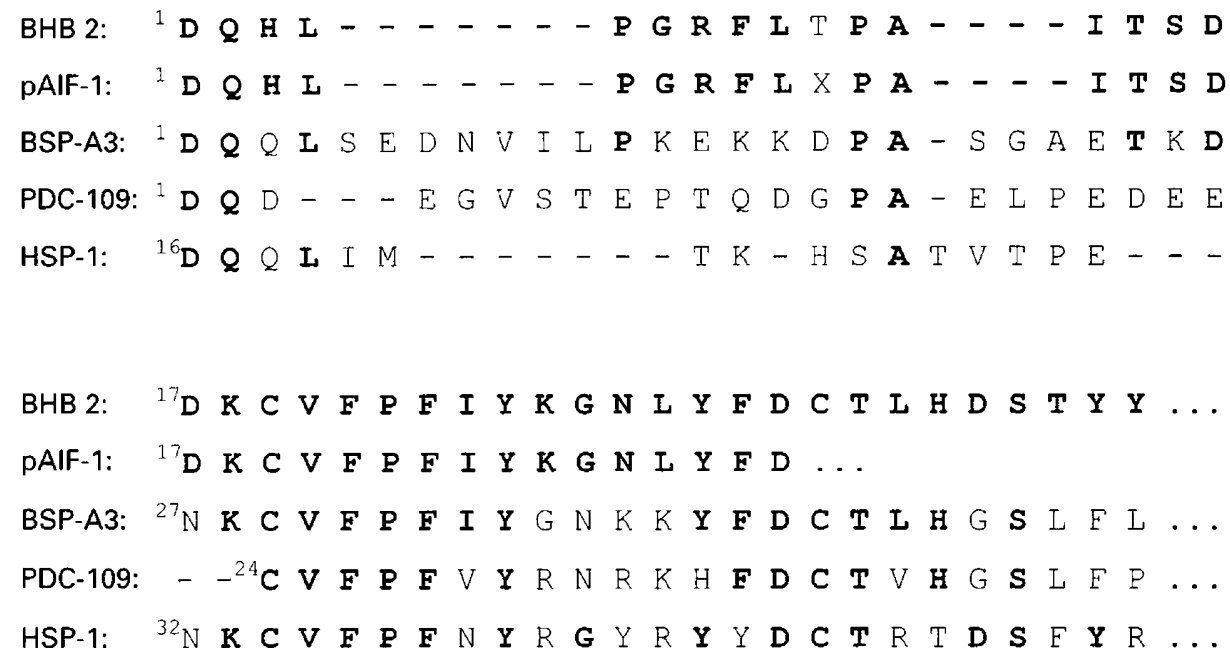

Fig. 2. Comparison of the N-terminal sequence of boar heparin-binding protein BHB-2 with homologous sequences of leucocyte cell-cell adhesion regulator (pAIF-1) from boar seminal plasma and proteins from bull (BSP-A3 and PDC-109) and stallion (HSP-1) seminal plasma. Identical amino acid residues are shown in bold letters.

did not show the presence of any free -SH groups in the nonreduced DQH protein, whereas reduction and alkylation resulted in the formation of eight carboxymethylcysteine residues $\mathrm{mol}^{-1}$ of the protein. These results provide evidence for the presence of four disulphide bridges in the $\mathrm{DQH}$ molecule; $\mathrm{AQN}$ and $\mathrm{AWN}$ spermadhesins contain only two. In addition, the amino acid composition of the $\mathrm{DQH}$ protein was characterized by a high content of tyrosine and threonine and a low content of glycine.

Amino acid analysis was also used for the determination of the galactosamine and glucosamine content; all proteins contained glucosamine, while only $\mathrm{DQH}$ and $\mathrm{AWN}-1$ proteins contained galactosamine.

\section{Immunological characterization of boar heparin-binding proteins}

Anti-AQN-1 serum yielded a strong reaction with the AQN spermadhesins (BHB-3-BHB-5) and a weaker reaction with the $\mathrm{DQH}$ protein (BHB-2). The antiserum titre in the reaction with $1 \mathrm{\mu g}$ of $A Q N-1$ was $1: 300000$ and with the same amount of DQH it was 1:120000. Both native and reduced proteins reacted with equal intensity. No reaction was observed in the case of AWN proteins. Anti-AWN-1 serum reacted strongly with the AWN spermadhesins (BHB-7-BHB-9); in the case of AWN-1 protein, the titre was 1:600000 for $1 \mu \mathrm{g}$ of the antigen. No reaction was observed with the $\mathrm{DQH}$ protein and $\mathrm{AQN}$ spermadhesins.

The $14 \mathrm{kDa}$ HNK protein from the BHB-6 fraction did not react with antibodies against either $A Q N$ or $A W N$ spermadhesins (Table 2). Only AWN-1 yielded a weak reaction with the non-immune rabbit serum; other protein fractions did not react at all. Immunoreactions of the proteins after transblotting on nitrocellulose sheets were in agreement, but $\mathrm{DQH}$ protein reacted with anti-AQN-1 serum with the same intensity as did AQN-1.

\section{Interaction of separated sperm proteins with different ligands}

The ligand binding ability of the purified heparin-binding proteins was studied by three methods: (i) detection of proteins separated by SDS-PAGE followed by transfer to nitrocellulose membranes using biotinylated ligands and avidin-peroxidase (the reaction with concanavalin $\mathrm{A}$ was also studied using non-derivatized horse radish peroxidase); (ii) interaction of proteins immobilized on microtitre polystyrene plates with biotinylated ligands and avidin-peroxidase in ELBA tests; (iii) affinity chromatography on gelatin-agarose and heparin-polyacrylamide gel followed by phosphoryl choline elution. Results are summarized in Fig. 3 and Tables 2 and 3. All BHB proteins bound to the biotinylated polyacrylamide derivative of heparin but with varying affinity; the strongest interaction was observed in the case of AWN-1 spermadhesin from the BHB-7 fraction. All isolated proteins interacted with concanavalin $A$ indicating their glycoprotein nature. The ELBA tests and electrophoretic detection of the separated proteins showed that the AWN-1 protein had the greatest affinity for solubilized zona pellucida; a weaker interaction was observed in the case of $\mathrm{DQH}$ and $\mathrm{AQN}$ proteins. The interaction of $\mathrm{AWN}-2$ with zona pellucida was weak, whereas the interaction of $\mathrm{DQH}, \mathrm{AQN}$ spermadhesins and AWN-1 was stronger (Table 2). In ELBA tests, all boar heparin-binding proteins interacted with zona pellucida. AWN spermadhesins bound to zona pellucida and proteinase inhibitors more strongly than AQN spermadhesins and DQH protein. AWN-1 showed the strongest interaction with zona pellucida and with soya bean proteinase inhibitor (Fig. 3). In all cases, the reactivity was dependent on protein concentration. Affinity chromatography experiments showed that the $\mathrm{DQH}$ and $A W N$ proteins but not the AQN proteins bind to gelatin-agarose and that the $\mathrm{DQH}$ protein and the dominant AQN-1 spermadhesin are phosphoryl choline-binding 


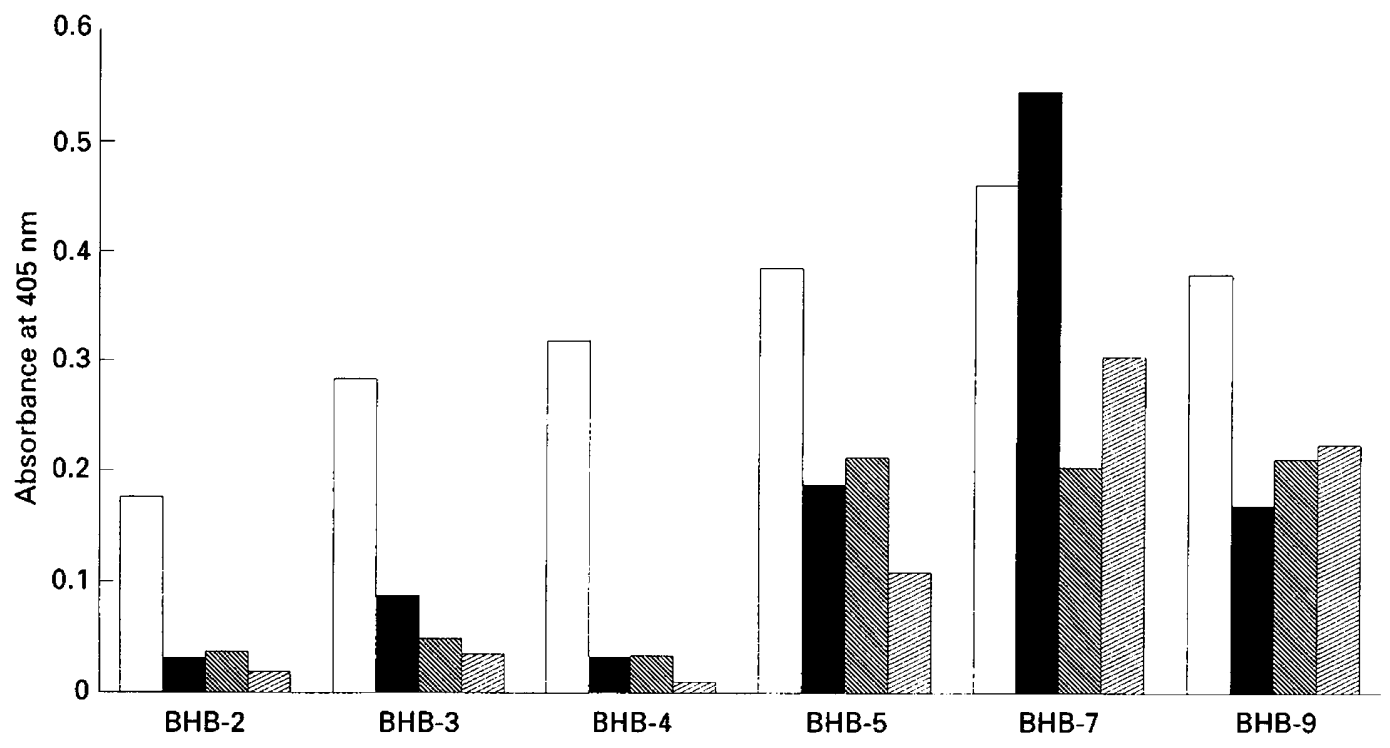

Fig. 3. Binding of different types of ligand by boar heparin-binding proteins BHB-2-BHB-5, BHB-7 and BHB-9 ( $2.5 \mu \mathrm{g}$ of each) in an enzyme-linked binding assay. Polyacrylamide derivative of heparin $(\square, 5 \mu \mathrm{g})$; solubilized

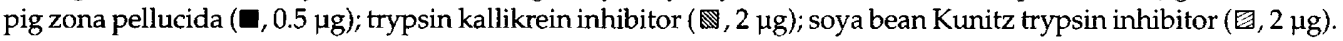

Table 2. Reaction of blotted boar heparin-binding proteins BHB-2-BHB-9 electrophoretically separated with rabbit antisera to $A Q N$ and $A W N$ proteins, biotinylated solubilized pig zona pellucida and concanavalin A

\begin{tabular}{|c|c|c|c|c|c|c|}
\hline \multirow[b]{2}{*}{ Heparin-binding protein } & \multirow[b]{2}{*}{ N-terminal } & \multirow[b]{2}{*}{$M_{\mathrm{r}}(\mathrm{kDa})$} & \multicolumn{4}{|c|}{ Reaction with: } \\
\hline & & & anti-AQN-1 & anti-AWN-1 & zona pellucida & concanavalin $\mathrm{A}$ \\
\hline BHB-2 & DQH- & 13 & +++ & - & ++ & + \\
\hline BHB-3 & AQN- & 13 & +++ & - & ++ & + \\
\hline \multirow[t]{2}{*}{ BHB-4 } & $\mathrm{AQN}-$ & 14 & ++ & - & +++ & + \\
\hline & & 16 & ++ & - & + & + \\
\hline BHB-5 & $\mathrm{AQN}-$ & 12 & ++ & - & ++ & + \\
\hline \multirow[t]{3}{*}{ BHB-6 } & HNK- & 14 & - & - & - & + \\
\hline & AWN- & 16 & - & ++ & +- & + \\
\hline & AWN- & 17 & - & ++ & +- & + \\
\hline BHB-7 & AWN- & 14 & - & +++ & ++++ & + \\
\hline \multirow[t]{2}{*}{ BHB-8 } & AWN- & 14 & - & ++ & ++ & + \\
\hline & blocked & 70 & - & - & - & + \\
\hline BHB-9 & blocked & 16 & - & +++ & + & + \\
\hline
\end{tabular}

,+ positive reaction; the number of + indicates the relative immunoreactivity and/or binding to zona pellucida of each protein. +- , extremely weak pattern.

Table 3. Interaction of separated boar sperm proteins with gelatin and phosphoryl choline as determined by affinity chromatography

\begin{tabular}{lcc}
\hline Sperm proteins & Gelatin & Phosphoryl choline $^{\mathrm{a}}$ \\
\hline DQH & ++ & ++ \\
AQN & - & $+^{\mathrm{c}}$ \\
AWN & $++^{\mathrm{d}}$ & -
\end{tabular}

++ , complete binding; + , incomplete binding.

"Proteins bound to gelatin-agarose and eluted with 4 mol urea $\mathrm{l}^{-1}$.

'Proteins bound to heparin-polyacrylamide gel and eluted with phosphoryl choline.

"AQN-1 protein predominated in the eluted fraction.

'All AWN spermadhesins in the eluted fraction. 
proteins (Table 3). Individual AQN forms differed in their binding properties.

\section{Binding of boar heparin-binding proteins to epididymal spermatozon}

The ability of the DQH protein to bind to spermatozoa was examined using biotinylated protein and epididymal spermatozoa. Biotinylated DQH protein was found to bind to epididymal spermatozoa immobilized in microtitre plates.

To localize the site of the attachment of the spermadhesin on the sperm cell, epididymal boar spermatozoa were incubated with biotinylated $\mathrm{DQH}$ solution and the binding of this protein was detected by FITC-avidin and visualized under the immunofluorescent microscope. The results of this experiment are shown in Fig. 4. The control with nonimmune serum was negative (not shown). Figure 4a shows that biotinylated $\mathrm{DQH}$ attached to the acrosome of epididymal spermatozoa. Similar results were obtained with spermatozoa treated with biotinylated AQN-1 and AWN-1 (Fig. 4b, c).

\section{Agglutination of splenocytes}

The addition of 250 or $100 \mu \mathrm{g} \mathrm{DQH} \mathrm{ml} \mathrm{H}^{-1}$ cell suspension of splenocytes was followed by $80-90 \%$ agglutination of splenocytes (Fig. 5). Incubation of the splenocytes with $20 \mu \mathrm{gr}$ $\mathrm{DQH} \mathrm{m} \mathrm{m}^{-1}$ cell suspension agglutinated the cells by $20 \%$. No cell agglutination was observed with $1 \mu \mathrm{g} \mathrm{DQH} \mathrm{ml}$ splenocyte suspension.

\section{Discussion}

In addition to spermadhesins of the $A Q N$ and $A W N$ families, the heparin-binding fraction of boar seminal plasma contained HNK and DQH proteins. The HNK protein showed close homology to the dominant basic protein of human seminal plasma (Lilja and Jeppsson, 1985) that is a cleavage product of the human vesicle protein semenogelin I. The enzyme responsible for the cleavage is a prostate kallikrein-like protease (Robert et al., 1997). The presence of a semenogelin-like protein or its degradation product (HNK protein) among boar heparin-binding proteins has not been reported so far. Determination of $\mathrm{N}$-terminal amino acid residues of the $\mathrm{DQH}$ protein (BHB-2) showed that this protein is characterized by homology to the main acidic proteins of bull seminal plasma (PDC-109 and BSP-A3) (Seidah et al., 1987) and to HSP-1 and HSP-2 of stallion seminal plasma (Calvete of al., 1995). Affinity chromatography experiments showed that the $\mathrm{DQH}$ protein bound to gelatin-agarose, as does bull or stallion major seminal protein (Manjunath et al., 1987; Calvete et al., 1995). The DQH protein also showed phosphoryl choline-binding ability as do the bull major seminal proteins (Calvete et al., 1996). All these proteins isolated in this study also exhibit a very high level of sequence homology with the collagen binding domain of the type II in fibronectin (Bannayi et al.,
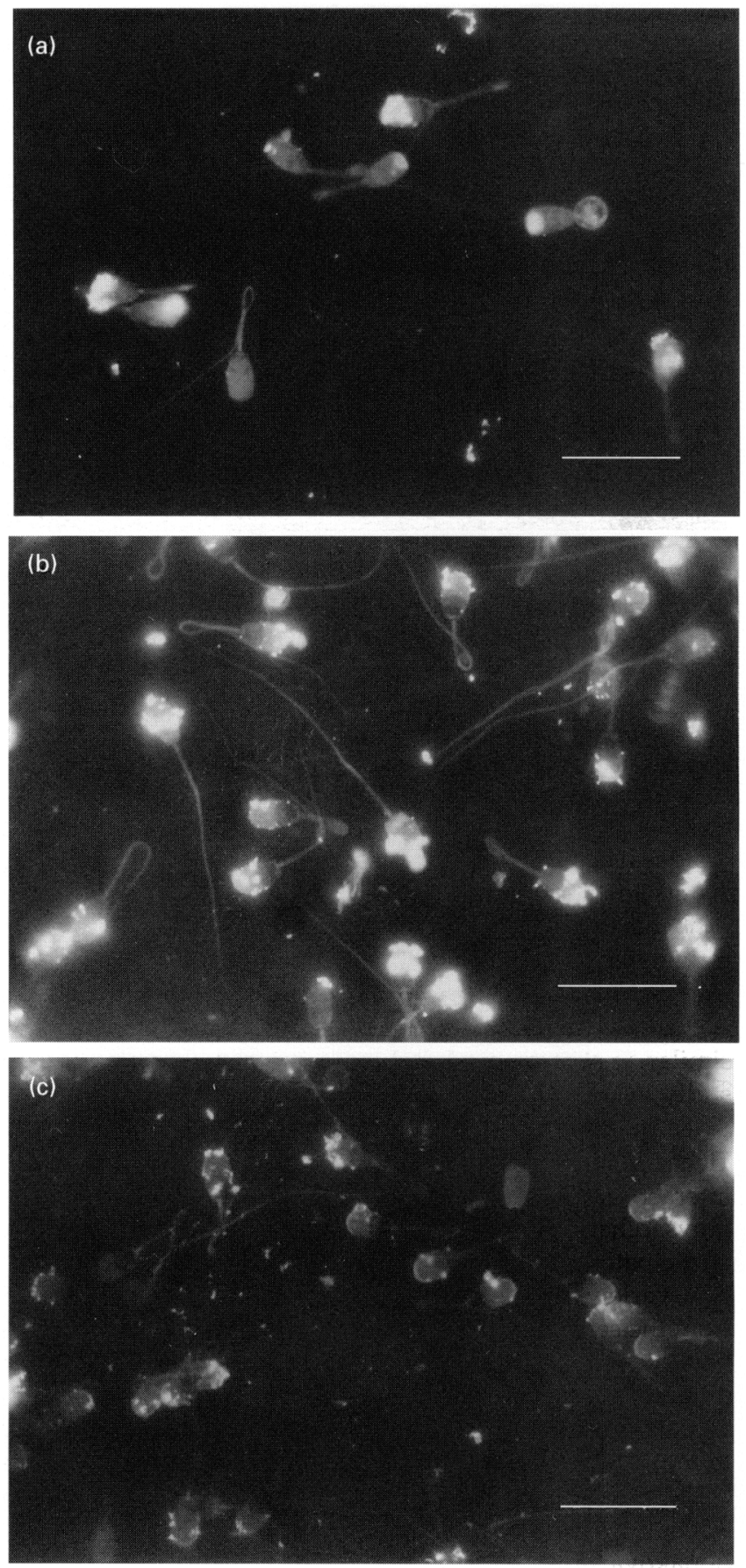

Fig. 4. Binding of (a) DQI (b) $A Q N-1$ and (c) $A W N-1$ proteins from boar seminal phosma to boar epididymal spermatozon. Scale bars represent $20 \mu \mathrm{m}$.

1990). The bull and stallion seminal plasma proteins play an important role in the process of sperm capacitation caused by heparin-like glycosaminoglycans (Miller it al., 1990). DQH protein is also spermadhesin-like because its biotinylated derivative adheres to epididymal spermatozoa in iitro. The existence of a boar seminal plasma protein with the N-terminal sequence DQH was first reported by Sanz of al. (1993). Our results suggest that the DQH sperm surface protein described here is identical with the adhesion 


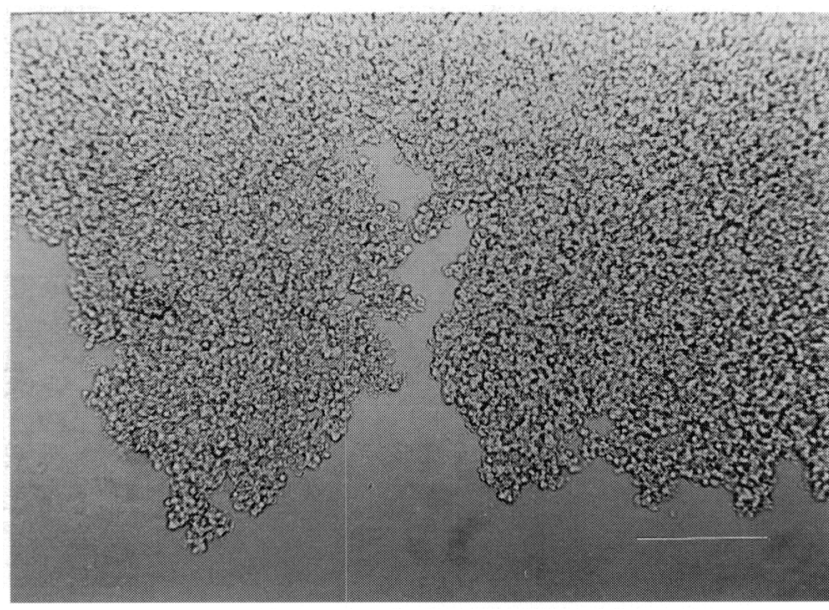

Fig. 5. Agglutinating activity of $\mathrm{DQH}$ sperm surface protein from boar seminal plasma on mouse splenocytes. Scale bar represents $140 \mu \mathrm{m}$.

inducing protein (pAIF-1) isolated from boar seminal vesicle fluid by Hadjisavas et al. (1994). pAIF-1 has been implicated in mediating the activation of leucocytes at the site of inflammation in the female reproductive tract that occasionally occurs following insemination at mating (Hadjisavas et al., 1994). In the present study, DQH was found to agglutinate mouse splenocytes. Therefore, it is probable that $\mathrm{DQH}$ participates in the inflammatory process. Calvete et al. (1997) recently isolated and characterized a heparin- and phosphoryl choline-binding protein from boar and stallion seminal plasma. The primary structure was similar to that of the DQH protein isolated in the present study which has recently been characterized ( $\mathrm{K}$. Bezouška, J. Sklenář, P. Novák, P. Halada, V. Havlíček, M. Kraus, M. Tichá, V. Jonáková, unpublished). The ability of DQH to interact strongly with heparin- and chondroitin-like polysaccharides (Tichá et al., 1998) suggests that it also participates in the regulation of sperm capacitation.

A variety of heparin-binding proteins has been isolated from the seminal plasma of different species and similarities have been observed among sperm proteins isolated from different mammalian species. This phenomenon was revealed by $\mathrm{N}$-terminal amino acid sequence homology and immunochemical methods. However, the relative amounts of the different types of sperm protein in the heparin-binding fractions obtained from different species differ significantly (Jonáková, unpublished).

The heparin-binding proteins of boar seminal plasma may be divided into three groups: (i) spermadhesins of the AQN and AWN families; (ii) DQH sperm surface protein; and (iii) HNK protein. While AQN and AWN spermadhesins represent major protein components of boar seminal plasma, homologous proteins found in the seminal plasma of bulls (aSFP; Calvete et al., 1996) and stallions (HSP5; Bellair et al., 1997) are present in smaller amounts. The minor DQH sperm protein of boar seminal plasma is homologous to the major components of bull and stallion seminal plasma (PDC-109, BSP-A3, HSP-1 and HSP-2; Seidah et al., 1987; Calvete et al., 1995). Detection of HNK protein in the heparin-binding fraction of the boar seminal plasma represents one of the few examples of homologous proteins in boar and human seminal plasma. The human analogue of the HNK protein can be isolated as a major component from the heparinbinding fraction of human seminal plasma (Jonáková, unpublished results).

Calvete et al. $(1993 \mathrm{a}, \mathrm{b})$ reported that only some of the boar spermadhesins are glycoproteins and suggested that the glycosylation of sperm proteins modulated their ligandbinding activity. Our results indicate that all spermadhesins isolated from boar seminal plasma are glycosylated. Amino sugars were detected in all purified heparin-binding fractions and all proteins interacted with concanavalin A (Tichá, unpublished). This discrepancy might be explained by the use of different starting material for the isolation of spermadhesins.

$A Q N, A W N$ and DQH proteins bound STI and TKI from bovine organs with different affinities. AQN-3, AWN-1 and AWN-2 bound both inhibitors strongly, the binding ability of AQN-1, AQN-2 and DQH was weak. However, Sanz et al. (1992) reported that $A Q N-1$ and $A W N$, but not AQN-3, bound proteinase inhibitors. We suggest that the weak binding ability of $\mathrm{AQN}-1$ reported here resulted from glycosylation of the protein. Calvete et al. (1994) reported that glycosylated spermadhesins bound proteinase inhibitors weakly compared with the strong binding abilities of deglycosylated AWN-1. Spermadhesins that bind proteinase inhibitors strongly may have a role in preventing a premature acrosome reaction.

Immunological properties of isolated protein fractions from boar seminal plasma were studied using polyclonal anti-AQN-1 and anti-AWN-1 antibodies. Two different methods were used: ELISA and immunodetection of electrophoretically separated proteins transferred to nitrocellulose membranes. Anti-AWN antibodies reacted with proteins belonging to the AWN family and anti-AQN antibodies reacted with proteins belonging to the AQN family. Crossreactivity was observed in the $\mathrm{DQH}$ protein even though it belongs to a different family of sperm proteins. This unexpected finding suggests that the threedimensional arrangement of the protein molecules determines their antigenic properties. Determination of $\mathrm{N}$ terminal amino acid sequences should prove that $\mathrm{DQH}$ and $A Q N$ do not form a complex by aggregation of the protein molecules. The crossreactivity of DQH with anti-AQN 1 could be investigated further by immunological detection of proteins homologous to spermadhesins in tissues and organs of the same animal species or by finding homologous proteins in different animal species. It is likely that the immunological reactions follow a much more complicated molecular mechanism than previously thought.

Our results are in agreement with the current opinion that the proteins located on the sperm surface are involved in the complex chain of events leading to sperm capacitation, gamete recognition and binding to the ovum. Individual sperm proteins that differ in their binding properties might have different roles and participate in the process in different phases and at different locations.

The authors are grateful to M. Hošková for skillful technical assistance, J. Žbrožek for the amino acid analyses, ing. Z. Voburka for $\mathrm{N}$-terminal amino acid sequence determination, and J. Jonák 
for fruitful discussion. This work was supported by the Grant Agency of the Czech Republic Grant Nos 303/96/0844 and 524-96K162, the Grant Agency of Charles University Grant No. 92/1995, and by the Ministry of Education of the Czech Republic Grant No. VS 96141.

\section{References}

Altschul SF, Gish W, Miller W, Myers EW and Lipman DJ (1990) Basic local alignment search tool Journal of Molecular Biology $215403-410$

Bányai L, Trexler MA, Koncz S, Gyenes M, Sipos G and Pathy L (1990) The collagen-binding site of type-II units of bovine seminal fluid protein PDC109 and fibronectin European Journal of Biochemistry 193 801-806

Bellair S, Hess O, Ekhlasi M, deWilke IG, Neumann U and Töpfer-Petersen E (1997) Expression of the heparin-binding protein HSP-1 in the reproductive tract of the stallion Reproduction in Domestic Animals 3289

Calvete JJ, Solís D, Sanz L, Díaz-Mauriño T, Schäfer W, Mann K and TöpferPetersen E (1993a) Characterization of two glycosylated boar spermadhesins European Journal of Biochemistry 218 719-725

Calvete JJ, Sanz L, Dostálová Z and Töpfer-Petersen E (1993b) Characterization of AWN-1 glycosylated isoforms helps define the zona pellucida and serine proteinase inhibitor-binding region on boar spermadhesin FEBS Letters 334 37-40

Calvete JJ, Solís D, Sanz L, Díaz-Mauriño T, Schäfer W, Mann K and TöpferPetersen E (1994) Glycosylated boar spermadhesin AWN-1 isoforms. Biological origin, structural characterization by lectin mapping, localization of O-glycosylation sites, and effect of glycosylation on ligand binding Biological Chemistry Hoppe Seyler 375 667-673

Calvete JJ, Mann K, Schäfer W, Sanz L, Reinert M, Nessau S, Raida M and Töpfer-Petersen E (1995) Amino acid sequence of HSP-1, a major protein of stallion seminal plasma: effect of glycosylation on its heparin- and gelatinbinding capabilities Biochemical Journal (London) 310 615-622

Calvete JJ, Varela PF, Sanz L, Romero A, Mann K and Töpfer-Petersen E (1996) A procedure for the large-scale isolation of major bovine seminal plasma proteins Protein Expression and Purification 8 48-56

Calvete JJ , Raida M, Gentzel M, Urbanke C, Sanz L and Töpfer-Petersen E (1997) Isolation and characterization of heparin- and phosphorylcholinebinding proteins of boar and stallion seminal plasma. Primary structure of porcine pB1 FEBS Letters 407 201-206

Einspanier R, Krause I, Calvete JJ, Töpfer-Petersen E, Klostermeyer $\mathbf{H}$ and Karg H (1994) Bovine seminal plasma aSFP: localization of disulfide bridges and detection of three different isoelectric forms FEBS Letters 344 61-64

Hadjisavas M, Armstrong DT and Seamark RF (1994) Purification of a cell-cell adhesion regulator from porcine seminal vesicle fluid Biochemical and Biophysical Research Communications 205 1206-1216

Hedrick JL and Wardrip NJ (1986) Isolation of the zona pellucida and purification of its glycoprotein families from pig oocytes Analytical Biochemistry 157 63-70

Hokke CH, Damm JBL, Penninkhof B, Aitken RJ, Kamerling IJP and Vliegenthart FG (1994) Structure of the O-linked carbohydrate chains of porcine zona pellucida glycoproteins European Journal of Biochemistry 221 491-512

Jonáková V, Sanz L, Calvete JJ, Henschen A, Čechová D and Töpfer-Petersen E (1991) Isolation and biochemical characterization of a zona pellucidabinding glycoprotein of boar spermatozoa FEBS Letters 280 183-186

Jonáková V, Tichá M, Kraus M and Čechová D (1995) Multifunctional sperm protein in gametic interaction Fertilität 11 115-118

Klein J, Kraus M, Tichá M, Železná B, Jonáková V and Kocourek J (1995) Water-soluble poly(acrylamide-allylamine) derivatives of saccharides for protein-saccharide binding studies Glycoconjugate Journal 12 51-54

Kwok SCM, Soares MJ, McMurtry JP and Yurewicz EC (1993) Binding characteristics and immunolocalization of porcine seminal protein, PSP-I Molecular Reproduction and Development 35 244-250

Laemmli UK (1970) Cleavage of structural proteins during the assembly of the head of bacteriophage T4 Nature (London) 227 680-685

Liberda J, Kraus M, Tichá M and Jonáková V (1997a) Affinity purification of spermadhesins of AWN family and their binding properties International Journal of Biochromatography 3 281-292

Liberda J, Tichá M and Jonáková V (1997b) Preparation of fluoresceinlabelled and biotinylated derivatives of polysaccharides for lectin-saccharide binding studies Biotechnology Techniques 11 265-267

Lilja $\mathbf{H}$ and Jeppsson JO (1985) Amino acid sequence of the predominant basic protein in human seminal plasma FEBS Letters 182 181-184

Lilja H, Abrahammson PA and Lundwall A (1989) Semenogelin, the predominant protein in human semen. Primary structure and identification of closely related proteins in the male accessory glands and on the spermatozoa Journal of Biological Chemistry 264 1894-1900

Manjunath P, Sairam MR and Uma J (1987) Purification of the four gelatinbinding proteins from bovine seminal plasma by affinity chromatography Bioscience Reproduction 7 231-238

Miller DJ, Winer MA and Ax RL (1990) Heparin-binding proteins from seminal plasma bind to bovine spermatozoa and modulate capacitation by heparin Biology of Reproduction 42 899-915

Parry RV, Barker PJ and Jones R (1992) Characterization of low $M_{\mathrm{r}}$ zona pellucida binding proteins from boar spermatozoa and seminal plasma Molecular Reproduction and Development 33 108-115

Robert M, Gibbs BF, Jacobson E and Gagnon C (1997) Characterization of prostate-specific antigen proteolytic activity on its major physiological substrate, the sperm motility inhibitor precursor/semenogelin I Biochemistry $363811-3819$

Sanz L, Calvete JJ, Jonáková V and Töpfer-Petersen E (1992) Boar spermadhesins $A Q N-1$ and $A W N$ are sperm-associated acrosin inhibitor acceptor proteins FEBS Letters 300 63-66

Sanz L, Calvete JJ, Mann K, Gabius H-J and Töpfer-Petersen E (1993) Isolation and biochemical characterization of heparin-binding proteins from boar seminal plasma: a dual role for spermadhesins in fertilization Molecular Reproduction and Development 35 37-43

Seidah NG, Manjunath P, Rochemont J and Chrétien M (1987) Complete amino acid sequence of BSP-A3 from bovine seminal plasma Biochemical Journal 243 195-203

Tìchá M, Železná B, Jonáková V and Filka K (1994) Immobilization of heparin on polyacrylamide derivatives Journal of Chromatography B $656423-426$

Tichá M, Kraus M, Čechová D and Jonáková V (1998) Saccharide-binding properties of boar $A Q N$ spermadhesins and $D Q H$ sperm surface protein Folia Biologica (Praha) 44 15-21

Töpfer-Petersen E, Calvete JJ, Sanz L and Sinowatz F (1995) Carbohydrate- and heparin-binding proteins in mammalian fertilization Andrologia 27 303-324

Towbin H, Staehelin $\mathbf{T}$ and Gordon $\mathbf{J}$ (1979) Electrophoretic transfer of proteins from polyacrylamide gels to nitrocellulose sheets: procedure and some applications Proceedings of the National Academy of Sciences USA 76 $4350-4354$

Tsunasawa S, Kondo J and Sakiyama F (1985) Isocratic separation of PTHamino acids at picomole level by reverse-phase HPLC in the presence of sodium dodecyl sulfate Journal of Biochemistry 97 701-704

Williams CA (1971) Immunoelectrophoretic analysis. In Methods in Immunology and Immunochemistry III pp 234-240 Eds CA Williams and MV Chase. Academic Press, New York 